Fourth International Conference on Sustainable Construction Materials and Technologies http://www.claisse.info/Proceedings.htm

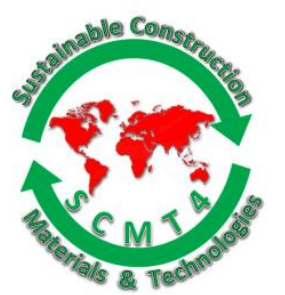

SCMT4

Las Vegas, USA, August7-11, 2016

\title{
Strength and Durability of Cement-Based Materials Incorporated with Low Grade Kaolinitic Calcined Clay
}

\author{
Mark Bediako ${ }^{1 \mathrm{a}}$, John Tristan Kevern², Johny Solomon Ankrah ${ }^{1 \mathrm{~b}}$ \\ ${ }^{I}$ CSIR- Building and Road Research Scientist, Kumasi, Ghana \\ ${ }^{2}$ University of Missouri- Kansas City, Civil and Mechanical Engineering Department, United States
}

\begin{abstract}
Existing literature has shown that high grade kaolin can be processed into metakaolin to replace portions of Portland cement without compromising the properties of cement-based materials. However, , there is limited literature pertaining to the use of clays with low content of kaolinite as a pozzolanic materials, even though lower grade kaolin exists abundantly on the earth crust and in almost every country. This work analyzed clay obtained from Ghana. The clay material was calcined at temperatures ranging from $600^{\circ} \mathrm{C}$ to $1000^{\circ} \mathrm{C}$. The raw clay characterization was determined based on geotechnical properties and the use of solid state ${ }^{27} \mathrm{Al}$ Magic angle spinning nuclear magnetic resonance (MAS NMR). Strength activity index prescribed by the American Society for the Testing of Materials (ASTM) was used as a method of determining the appropriate temperature for clay calcination. Sorptivity analysis was determined as a way of checking the durability of cement and calcined clay mixtures. The results of the test confirmed that the clay material used was a low grade kaolinitic type. The most suitable temperature that yielded maximum strength from the mortar mixtures between cement and calcined clays was at $800^{\circ} \mathrm{C}$. The sorptivity test also showed that the incorporation of calcined clay in cement based products refined the pore structure which may enhance durability. The refinement of the pore structure was determined by studying the sorptivity coefficient values which showed that the material resisted the ingress of ions. The study recommended the use of low grade calcined kaolinitic clay as a suitable pozzolanic material.
\end{abstract}

\section{INTRODUCTION}

The use of calcined clays as Portland cement replacement material to formulate blended cementitious binders appears to be increasing in many developing countries including South American countries, Asian, and many African countries (Tironi et al, 2014; Escalera et al, 2014; Chakchouk et al, 2006). The prospects of using calcined clays are reported by several researchers who indicate that, not only does the calcined material improve the mechanical properties of cement-based materials such as concrete, mortar and paste, but also provides reduce cost of cement used in projects containing concrete or mortar. The reduced cement usage also translates to minimize carbon dioxide emissions in the environment (Bediako et al, 2012; Mitrović and Zdujić 2014; Alujas et al, 2015). The demand for Portland cement worldwide has been rising yearly and is estimated to hit about 5 billion tonnes by 2030 which will translates to more carbon dioxide 
emissions (Potgieter 2012). Lothenbach et al, (2011) reported that a more sustainable approach to cut down the increasing demand of cement in the near future would be the increased use of supplementary cementitious materials that includes calcined clays and shales and other industrial by-products like fly-ash, silica fumes, and slags. The calcination temperatures suitable to produce a good cement replacement material have been reported to be between $500^{\circ} \mathrm{C}$ and $900^{\circ} \mathrm{C}$ depending on the nature and type of clay (Tironi et al. 2012; Shvarzman et al. 2003).

Clays from different origins have different properties however the basic building blocks of tetrahedral and octahedral units are the same (Zhou and Keeling 2013). The reactivity of calcined clay with cement is influenced by its kaolinite content and the presence of impurities found in the clay. The impurities that are commonly found in clays include quartz, anatase, rutile, pyrite, siderite, feldspar, etc (Mitrović and Zdujić 2014). Clays with high kaolinite content ( $\geq 65 \%$ ) are classified as high purity clay whereas those with kaolinite content between $40 \%$ and $65 \%$ are classified as medium quality clay (Aras et al. 2007). Alujas et al. (2015) classified low grade kaolinitic clays as having kaolinite below $40 \%$. The earth crust has abundance of clay, however pure or high grade kaolinitic clays occur less abundantly and therefore processed high grade kaolinitic clays appear to be very expensive as a supplementary cementitious material (Alujas et al. 2015). Today a lot of efforts have been channeled into the development of clay such as montmorillonite, illitic which belongs to a 2:1 clay type and even low grade kaolinitic clays (i.e 1:1 clay type) as pozzolans because of its geographical advantage (Fernández et al. 2011; He et al, 1994; Maia et al. 2014).

Low grade kaolinitic clays occur naturally in the earth crust with associated non clay minerals. The content of kaolinites as well as non-clay minerals influence the quality and reactivity of calcined clays (Tironi et al. 2013). The origin and the geographical location of clay also have direct influence on the content of clay and non-clay material. This therefore suggests that clay from different areas or countries may contain different clay minerals. Alujas et al. (2015) have reported that there is a growing interest on the development of low grade kaolinitic clays as a pozzolanic material. Much literature exists on high grade kaolinitic clays but not on low grade ones (Maia et al. 2014; Bich et al. 2009). This therefore calls for the need to develop a lot of literature on the use of low grade kaolinitic clays as a supplementary cementitious material because of the material's geographical advantage. As almost all cement in Western Africa is imported, the ability to utilize a locally-available material presents an opportunity to reduce the carbon footprint of concrete works, but also improving the local economic situation. This study seeks to investigate the strength performance and durability of blended cements between calcined low grade kaolinitic clays and Portland cement.

\section{MATERIALS AND METHODS}

Materials. The materials that were used for the study were Portland cement meeting both ASTM C150 Type I and Type II classifications, clay material, graded sand, a chemical admixture and potable water. The Portland cement was obtained from Ash grove, Chanute, Kansas in the United States. Table 1 presents the properties of the cement. The clay material was obtained from Ghana in the Ashanti region area of the country. Table 2 presents the geotechnical properties of the clay. 
The clay is classified as silty clay with an actual clay content of $28.4 \%$. Graded sand which conformed to ASTM C778 was used for mortar specimens. Mixtures also included a polycarboxylate type high range water reducing (HRWR) admixture. Mixture water was potable municipal water from the University of Missouri- Kansas City (UMKC).

Table 1. Properties of Portland cement

\begin{tabular}{|l|c|}
\hline Property & ASTM Type I/II cement \\
\hline Physical & 401.7 \\
\hline Fineness $\left(\mathrm{m}^{2} / \mathrm{kg}\right)$ & 3.13 \\
\hline Specific gravity & \\
\hline Chemical & 20.49 \\
\hline $\mathrm{SiO}_{2}(\%)$ & 4.26 \\
\hline $\mathrm{Al}_{2} \mathrm{O}_{3}(\%)$ & 3.14 \\
\hline $\mathrm{Fe}_{2} \mathrm{O}_{3}$ & 63.48 \\
\hline $\mathrm{CaO}(\%)$ & 2.11 \\
\hline $\mathrm{MgO}(\%)$ & 2.90 \\
\hline $\mathrm{SO} 3(\%)$ & 0.49 \\
\hline $\mathrm{Na}_{2} \mathrm{O}+\mathrm{K}_{2} \mathrm{O}(\%)$ & 2.20 \\
\hline $\mathrm{LOI}(\%)$ & \\
\hline $\mathrm{Mineralogy}$ & 56 \\
\hline $\mathrm{C}_{3} \mathrm{~S}(\%)$ & 15 \\
\hline $\mathrm{C}_{2} \mathrm{~S}(\%)$ & 6 \\
\hline $\mathrm{C}_{3} \mathrm{~A}(\%)$ & 9 \\
\hline $\mathrm{C}_{4} \mathrm{AF}(\%)$ & \\
\hline
\end{tabular}

Table 2. Some geotechnical properties of the clay

\begin{tabular}{|l|l|l|l|l|}
\hline \multicolumn{2}{|l|}{ Particle Size Distribution (\%) } & & Soil type \\
\hline Clay & Silt & Sand & Gravel & Silty clay \\
\hline 28.4 & 19.5 & 52 & 0.1 & \\
\hline
\end{tabular}

\section{Methods}

Clay characterization. The raw clay was characterized based on its geotechnical properties and these properties included clay, silt and sand content. Aluminum structure of the clay was probed to determine if the clay was a 1:1 or 1:2 type using nuclear magnetic resonance (NMR). The NMR was a Tecmag Apollo Console (Houston, TX) with 8.45 T magnet and custom, single channel, 4 $\mathrm{mm}$ wide-bore NMR probe which evaluated ${ }^{27} \mathrm{Al}$. About $90 \mathrm{mg}$ of sample was taken for the analysis and signals were represented as chemical shift value; $\delta$ : ppm. The ${ }^{27} \mathrm{Al}$ frequency was 93.074 MHz. ${ }^{27} \mathrm{Al}$ spectrum was acquired with MAS spinning frequency, last delay and $90^{\circ}$ pulse length of $8 \mathrm{KHz}, 1 \mathrm{~s}$ and $2.5 \mu \mathrm{s}$, respectively. Aluminum nitrate $\left[\mathrm{Al}\left(\mathrm{NO}_{3}\right)\right]$ was used as the reference 
compound for ${ }^{27} \mathrm{Al}$. This experiment was performed at ambient temperature without any corrections for sample heating.

Clay calcination. The clay material was air-dried for about 72 hours and ground into fine particles. Ground air-dried clay material were placed in a ceramic bowl and placed in an electric furnace. The clay material was calcined at each temperatures of $600^{\circ} \mathrm{C}, 700^{\circ} \mathrm{C}, 800^{\circ} \mathrm{C}, 900^{\circ} \mathrm{C}$, and $1000^{\circ} \mathrm{C}$ in the furnace for 3 hours. After the calcination period, the furnace was switched off and the ceramic bowl and its content allowed to cool down in the furnace for about 24 hours. The calcined clay material was sieved through a $75 \mu \mathrm{m}$ sieve using a sieve shaker.

Strength determination. The strength activity index described in ASTM C311 was used for the strength determination of the mixtures between the calcined clays and Portland cement. The standard specifies a replacement value of $20 \%$ of Portland cement. The determination of strength activity index is given as:

$S A I=\frac{A}{B} \times 100 \%$

Where SAI= strength activity index

$\mathrm{A}=$ compressive strength of blended cement containing the calcined clay

$\mathrm{B}=$ compressive strength of the control

Mortar for the determination of strength performance was prepared in accordance with ASTM C305. The clay material calcined at the various temperatures was used to prepare different batches of mortars. Table 3 shows the mortar mixture proportions used for the SAI determination. The flow of the mortars were maintained using the HRWR, shown in Table 3 as weight of cementitious materials. Flow of the mortar was determined according to ASTM C1437. In addition to the 20\% replacement used to determine the ASTM C311 SAI, mix tures were also prepared with 10\%, 30\%, and $40 \%$ cement replacement using the calcining temperature with the highest strength, which was $800^{\circ} \mathrm{C}$ (Table 4). Samples were cured for 3, 7, or 28 days according to ASTM C192 in lime water. Compressive strength of the cube samples were performed according to ASTM C109.

Table 3. Mortar mixture proportions used for SAI determination

\begin{tabular}{|l|c|c|c|c|c|c|c|c|}
\hline \multirow{2}{*}{$\begin{array}{l}\text { Temp } \\
\left({ }^{\circ} \mathrm{C}\right)\end{array}$} & Mix & \multicolumn{2}{|l|}{ Mass $(\mathrm{g})$} & w/b & $\begin{array}{c}\text { HRWR } \\
(\%)\end{array}$ & $\begin{array}{c}\text { Flow } \\
(\%)\end{array}$ \\
\cline { 3 - 7 } & name & Cement & Clay & Sand & Water & & & 106 \\
\hline Control & Control & 500 & 0 & 1375 & 242 & 0.485 & 0.0 & 111 \\
\hline 600 & $20 \mathrm{P} 600$ & 400 & 100 & 1375 & 242 & 0.485 & 0.4 & 110 \\
\hline 700 & $20 \mathrm{P} 700$ & 400 & 100 & 1375 & 242 & 0.485 & 0.4 & 110 \\
\hline 800 & $20 \mathrm{P} 800$ & 400 & 100 & 1375 & 242 & 0.485 & 0.4 & 115 \\
\hline 900 & $20 \mathrm{P} 900$ & 400 & 100 & 1375 & 242 & 0.485 & 0.3 & 116 \\
\hline 1000 & $20 \mathrm{P} 1000$ & 400 & 100 & 1375 & 242 & 0.485 & 0.2 & \\
\hline
\end{tabular}


Table 4. Mortar mixture proportions of cement and various amounts of calcined clay

\begin{tabular}{|c|c|c|c|c|c|c|c|c|c|}
\hline \multirow[t]{2}{*}{ Mix } & \multicolumn{2}{|c|}{ Content (\%) } & \multirow[t]{2}{*}{$\mathrm{w} / \mathrm{b}$} & \multicolumn{4}{|c|}{ Mass (g) } & \multirow{2}{*}{$\begin{array}{c}\text { HRWR } \\
(\%)\end{array}$} & \multirow[b]{2}{*}{ Flow } \\
\hline & Cement & Clay & & Cement & Clay & Sand & Water & & \\
\hline Control & 100 & 0 & 0.485 & 740 & 0 & 2035 & 359 & 0.00 & 107 \\
\hline $10 \mathrm{P} 800$ & 90 & 10 & 0.485 & 666 & 74 & 2035 & 359 & 0.14 & 107 \\
\hline $20 \mathrm{P} 800$ & 80 & 20 & 0.485 & 592 & 148 & 2035 & 359 & 0.32 & 114 \\
\hline $30 \mathrm{P} 800$ & 70 & 30 & 0.485 & 518 & 222 & 2035 & 359 & 0.34 & 105 \\
\hline $40 \mathrm{P} 800$ & 60 & 40 & 0.485 & 444 & 296 & 2035 & 359 & 0.45 & 107 \\
\hline
\end{tabular}

Durability studies. Since durability-related distresses are a function of water and ion transport through the hydrated cement phase, the durability analysis for this study focused on absorption. Water sorptivity testing was performed in accordance with the ASTM C1585. The theory behind sorptivity states that if a mortar or concrete surface is exposed to wetting by water, then the cumulative water absorption, $i$ is proportional, during the initial absorption period, to the square root of elapsed wetting time $t$ :

$i=S \sqrt{t}$

$\mathrm{S}$ is the sorptivity measured in $\mathrm{g}$ per $\mathrm{mm}^{2}$ (of wetted area) per $\mathrm{sec}^{1 / 2}$ and is determined from the slope of the linear part of i versus $t^{1 / 2}$ curve (Sabir et al., 1998).

\section{RESULTS AND DISCUSSIONS}

Clay characterization. Figure 1 shows the solid state ${ }^{27} \mathrm{Al}$ MAS NMR of raw clay. Two resonating points corresponding to $68.30 \mathrm{ppm}$ and $-0.76 \mathrm{ppm}$ clearly observed. The two resonances indicate a 1:1 clay type i.e. an octahedral $\left(\mathrm{Al}^{(\mathrm{vi})}\right)$ and a tetrahedral $\left(\mathrm{Al}^{(\mathrm{iv})}\right)$ environment. Clay types having 1:1 structure are usually classified as a kaolinitic type of clay. The resonating point around $68.30 \mathrm{ppm}$ corresponds to a tetrahedral environment whereas the point at $-0.76 \mathrm{ppm}$ shows an octahedral environment confirming the studies of Hanna et al. (1995). From Table 2, the clay content that was present in the raw material was approximately $28 \%$. Corroborating the results between Table 2 and Figure 1, it could be stated that the clay is a low grade kaolinitic clay.

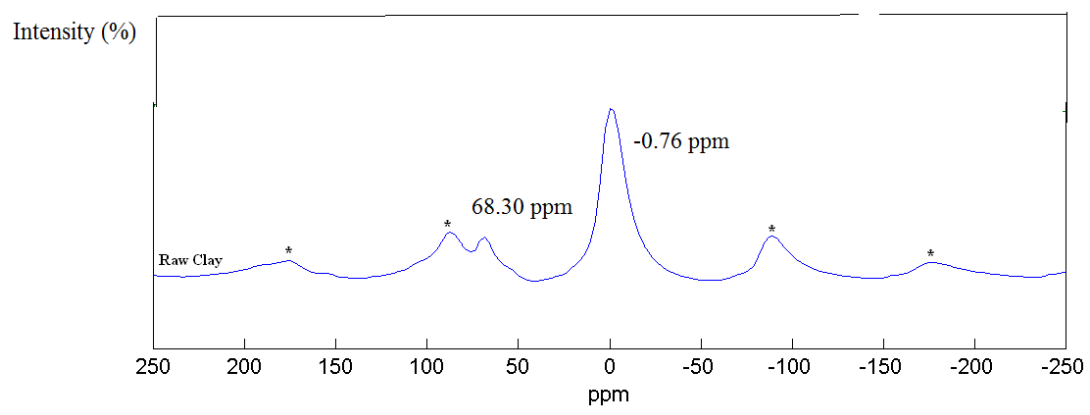

Figure 1. Solid state ${ }^{27} \mathrm{Al}$ MAS NMR of raw clay 
Strength performance (SAI). Figure 2 shows the strength activity index (SAI) of mortars containing calcined clay materials from $600-1000^{\circ} \mathrm{C}$. The ASTM C618 standard specification recommends that mortars containing $20 \%$ pozzolan must attain strength higher than $75 \%$ of the control mortar at both 7 and 28 days. All mixtures met the criteria at both ages. The SAI values showed that the mortar which contained calcined clay at $800^{\circ} \mathrm{C}(20 \mathrm{P} 800)$ had the maximum strengths at 7 and 28 days. The performance of 20P800 indicated that calcination temperature at $800^{\circ} \mathrm{C}$ was the most suitable temperature to provide more reactive phases in the calcined material.

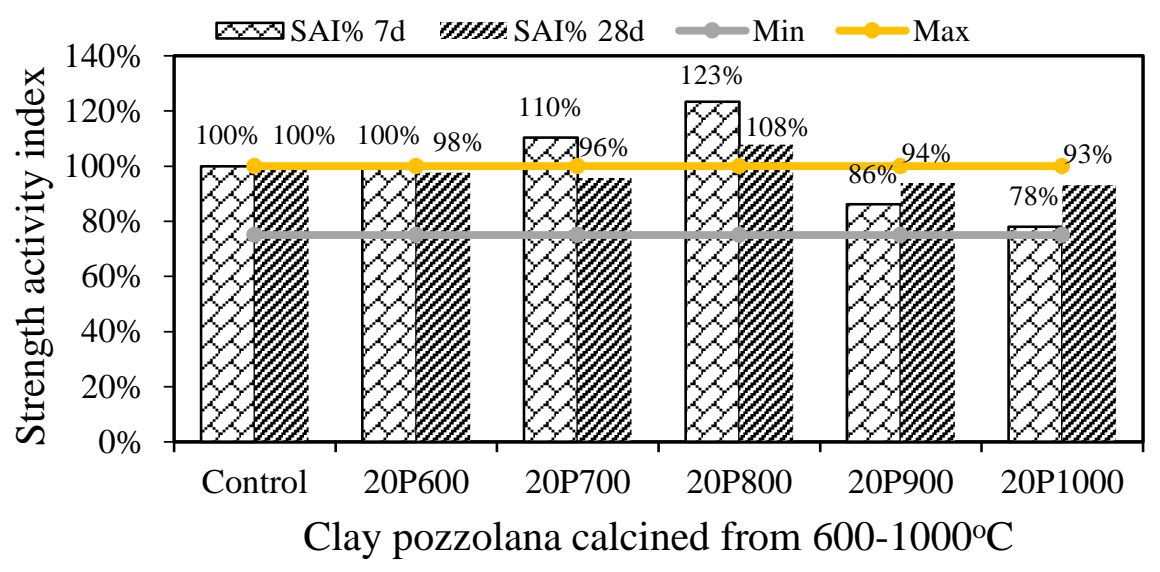

Figure 2. SAI of mortars containing calcined clay from $600-1000^{\circ} \mathrm{C}$

Compressive strength. Since $800^{\circ} \mathrm{C}$ had the highest SAI at the ASTM C311 prescribed $20 \%$ replacement, additional replacement levels were also investigated. Table 4 shows the mortar mixture proportions between Portland cement and calcined clay at $800^{\circ} \mathrm{C}$. Figure 3 presents the effect of the calcined material on strength of Portland cement. Compressive strength values obtained at 20\% (20P800) replacement of Portland cement gave the maximum strength values at 3, 7 and 28 days. Beyond 20\% replacement the strength was reduced. The performance of 20P800 indicated that $20 \%$ of calcined clay used to replace cement was very adequate to react and form stable compounds with Portland cement. This enhanced the strength performance of 20P800. Beyond $20 \%$, the calcined materials behaved as inactive materials.

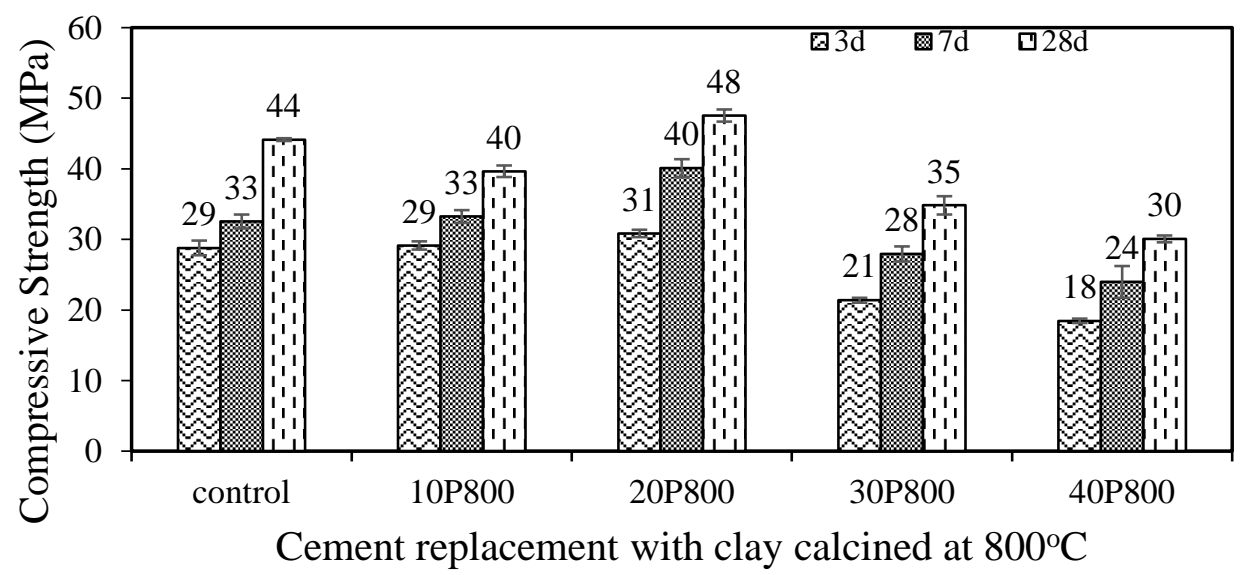

Figure 3. Compressive strength of mortars containing $10-40 \%$ calcined clay 
Durability test. Figure 4 shows the sorptivity analysis of the control mortar and with $20 \%$ replacement for cement with the $800^{\circ} \mathrm{C}$ calcined clay. Water sorptivity is a form of transport property of water or ions in unsaturated porous surfaces. It characterizes the material's ability to absorb and transmit water or ions through it by capillary suction (Sabir et al., 1998). The work of Siddique (2013) stated that reducing sorptivity is important to decrease ingress of chemical compounds including chlorides and sulfates which can cause serious damage.

Figure 4 shows initial and secondary sorptivity coefficients. The initial and secondary coefficients for the control mortar (CON) were 0.0107 and 0.0017 respectively whereas that of the blended cement mortar (20P) were 0.0028 and 0.0008 respectively. The initial sorptivity values of CON and 20P indicated that the blended mortar resisted ingress of ions more than the control. The trend was the same for the secondary sorptivity values. Generally, the sorptivity trends pointed out the higher resistance of mortar mixture containing $20 \%$ calcined clay than the unblended mortar mixture. This could mean that the blended mortar mixture contributed to pore size refinement of the mortar structure. In this case blended materials would be more durable than the unblended cement.

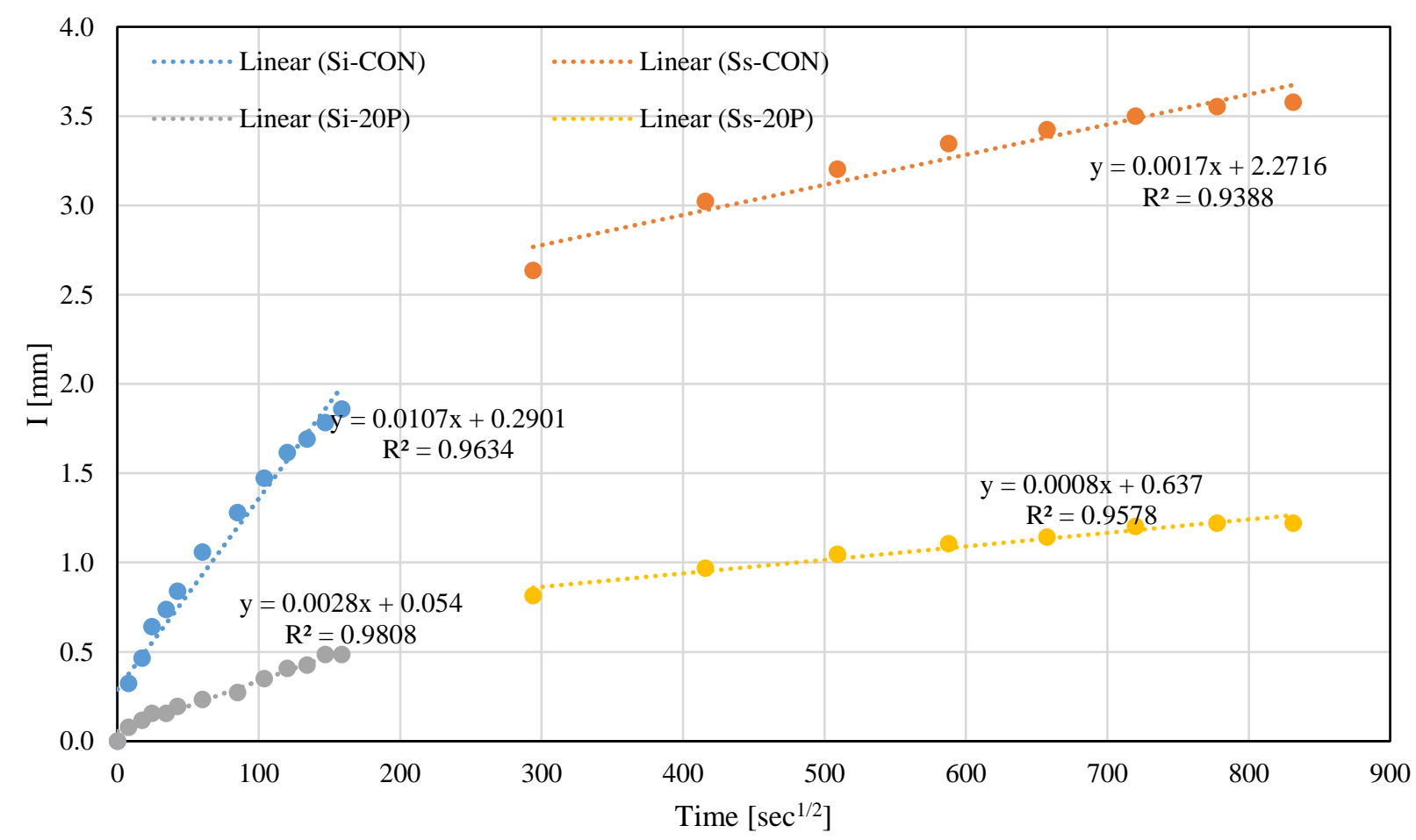

Figure 4. Sorptivity of control and calcined clay mortars

\section{CONCLUSIONS AND RECOMMENDATIONS}

Much of the literature supports using calcined high purity kaolin clay for cement replacement. The clay both reduces the carbon footprint of the concrete mixture, but also improves strength and durability. However, where pure kaolin clays are not found, lower purity, local materials have the potential for incorporation into concrete as well. This study investigated a mixed silty clay soil 
from Ghana calcined at various temperature. The following conclusions were drawn from the study:

1. The clay material characterization showed that the clay was a 1:1 kaolinitic clay type of low kaolinitic grade.

2. The calcination temperature of $800^{\circ} \mathrm{C}$ was suitable to produce more pozzolanic active phase in the calcined material hence increased the strength activity index

3. Calcined clays at $800^{\circ} \mathrm{C}$ replacing $20 \%$ of Portland cement led to enhancement in strength performance than even the unblended mixtures.

4. The application of $20 \%$ calcined clays in Portland cement positively influences pore size refinement of cement-based products, resists the ingress of ions and therefore ultimately improves durability of the material

Calcining this clay in Ghana has the potential to reduce the amount of imported clinker while improving the strength and durability of local concrete. The work suggests further studies are needed on the nature of hydrated compounds formed in the mixture between Portland cement and calcined clays and long-term performance in the field.

\section{REFERENCES}

Aras, A., Albayrak, M., Arikan, M., Sobolev, K. (2007). "Evaluation of selected kaolin clays as a raw material for the Turkish cement and concrete industry." Clay Miner. 42, 233-244.

Bich Ch., Ambroise, J., Péra, J. (2009). "Influence of degree of dehydroxylation on the pozzolanic activity of metakaolin.” Appl Clay Sci 44(3-4), 194-200.

Chakchouk, A., Samet, B., Mnif, T. (2006). "Study on the potential use of Tunisian clays as pozzolanic material." Applied Clay Science 33, 79-88.

Escalera, E., Tegman, R., Antti, M-L., Odén, M. (2014). "High temperature phase evolution of Bolivian kaolinitic-illitic clays heated to $1250{ }^{\circ}$ C." Applied Clay Science 101, 100-105.

Fernández López, R., Martirena Fernández, J.F., Scrivener, K. (2011). "The origin of the pozzolanic activity of calcined clay minerals: a comparison between kaolinite, illite and montmorillonite." Cem. Concr. Res. 41 (1), 113-122.

Hanna, R.A., Barrie, P.J., Cheeseman, C.R., Hills, C.D, Buchler, P.M., Perry, R. (1995). “Solid state Si and Al NMR and FTIR study of cement pastes containing industrial wastes and organics." Cem Concr Res 25, 1435-1444

He, C., Makovicky, E., Osbaeck, B. (1994). “Thermal stability and pozzolanic activity of calcined kaolin.” Appl. Clay Sci. 9 (3), 165-187.

Lothenbach, B., Scrivener, K., Hooton, R.D. (2011). "Supplementary cementitious materials." Cem. Concr. Res. 41 (7), 1244-1256.

Maia, A.Á.B., Angélica, R.S., de Freitas Neves, R., Pöllmann, H., Straub, C., Saalwächter, K. (2014). "Use of ${ }^{29} \mathrm{Si}$ and ${ }^{27} \mathrm{Al}$ MAS NMR to study thermal activation of kaolinites from Brazilian Amazon kaolin wastes." Appl. Clay Sci. 87, 189-196. 
Mitrović and Zdujić (2014). "Preparation of pozzolanic addition by mechanical treatment of kaolin clay." International Journal of Mineral Processing 132, 59-66.

Shvarzman, A., Kovler, K., Grader, G.S., Shter, G.E. (2003). "The effect of dehydroxylation/ amorphization degree on pozzolanic activity of kaolinite." Cem. Concr. Res. 33, 405-416

Tironi, A., Trezza, M.A., Scian, A. N. , Irassar, E.F (2014). "Potential use of Argentine kaolinitic clays as pozzolanic material." Applied Clay Science 101, 468-476.

Tironi, A., Trezza, M.A., Scian, A.N., Irassar, E.F. (2010). "Assessment of pozzolanic activity of different calcined clays.” Cement \& Concrete Composites 37, 319-327. 